\title{
LITERASI DIGITAL, MASSIVE OPEN ONLINE COURSES, DAN KECAKAPAN BELAJAR ABAD 21 MAHASISWA GENERASI MILENIAL
}

\section{DIGITAL LITERACY, MASSIVE OPEN ONLINE COURSES, AND $21^{\text {st }}$ CENTURY LEARNING ABILITIES OF MILLENNIAL GENERATION STUDENTS}

\author{
Imam Fitri Rahmadi ${ }^{1}$, Eti Hayati ${ }^{2}$ \\ ${ }^{1,2}$ Fakultas Keguruan dan Ilmu Pendidikan, Universitas Pamulang \\ Jalan Puspitek No. 23 Buaran Serpong, Kota Tangerang Selatan, Indonesia \\ 1'imamrahmadi@unpam.ac.id; ${ }^{2}$ dosen01391@unpam.ac.id \\ Diterima tgl. 19/9/2019; Direvisi tgl. 2/6/2020; Disetujui tgl. 5/6/2020
}

\begin{abstract}
Millennial generation students need to be equipped with adequate digital literacy in order to face the industrial revolution 4.0. Unfortunately, students' digital literacy particularly related to the $21^{\text {st }}$ century learning abilities is relatively low. This article critically discusses digital literacy massive open online courses (DL-MOOCs) need developments in higher education, including; 1) the need of digital literacy for academic purposes; 2) the development of MOOCs around the world and in Indonesia; 3) $21^{\text {st }}$ century learning abilities of millennial generation students. Study in this article is the result of preliminary research using literature review and survey methods involving 245 first-year millennial generation university students. The results revealed that; 1) digital literacy for academic purposes is needed since ample digital information has been utilised as learning resources and the learning process in higher education have commonly conducted in a digital environment; 2) the development of MOOCs opens extensive opportunities to be used as a massive, open, and online learning platform to improve digital literacy of millennial generation students; and 3) $21^{\text {st }}$ century learning abilities of millennial generation students are very low in the components of creative collaborator and innovative designer. These results indicate the urgency of MOOCs developments that focus on digital literacy for academic purposes.
\end{abstract}

Keywords: Digital Literacy, Massive Open Online Courses, $21^{\text {st }}$ Century Learning Abilities, Millennial Generation Students

\begin{abstract}
ABSTRAK
Mahasiswa generasi milenial perlu dibekali dengan literasi digital yang memadai dalam rangka menghadapi revolusi industri 4.0. Sayangnya, literasi digital mahasiswa terutama yang berkaitan dengan kecakapan belajar secara digital pada abad 21 masih tergolong rendah. Artikel ini mendiskusikan secara kritis kebutuhan pengembangan digital literacy massive open online courses (DL-MOOCs) di perguruan tinggi, meliputi; 1) kebutuhan literasi digital untuk keperluan akademik; 2) perkembangan MOOCs di dunia dan Indonesia; dan 3) kecakapan belajar abad 21 mahasiswa generasi milenial. Kajian dalam artikel merupakan hasil penelitian pendahuluan menggunakan metode kajian pustaka dan survei melibatkan 245 mahasiswa generasi milenial yang sedang menempuh perkuliahan pada tahun pertama. Hasil penelitian menunjukkan bahwa; 1) literasi digital untuk keperluan akademik sangat dibutuhkan karena hampir semua informasi yang dijadikan sumber belajar dan proses pembelajaran di perguruan tinggi sudah banyak dilakukan dalam lingkungan digital; 2) perkembangan MOOCs membuka kesempatan luas untuk dapat digunakan sebagai platform pembelajaran terbuka dan masif untuk meningkatkan literasi digital mahasiswa generasi milenial; dan 3) kecakapan belajar abad 21 mahasiswa generasi milenial masih sangat rendah pada komponen creative collaborator dan innovative designer. Hasil tersebut menunjukkan urgensi pengembangan MOOCs yang berfokus pada literasi digital untuk keperluan akademik.
\end{abstract}

Kata Kunci: Literasi Digital, Massive Open Online Courses, Kecakapan Belajar Abad 21, Mahasiswa Generasi Milenial 


\section{PENDAHULUAN}

Pada era revolusi industri 4.0 yang ditandai dengan teknologi digital yang super pintar mahasiswa generasi milenial perlu dibekali dengan literasi digital yang memadai (Schwab, 2016). Sebagai konsekuensinya, literasi yang dibutuhkan bukan sebatas literasi membaca, menulis, dan berhitung (calistung), tetapi juga literasi digital. Membekali literasi digital kepada mahasiswa generasi milenial saat menempuh pendidikan di perguruan tinggi diharapkan dapat mendorong terwujudnya generasi emas Indonesia yang berdaya saing dan unggul di masa depan.

Paul Gilster merupakan orang yang pertama kali menyetuskan istilah digital literacy atau literasi digital melalui buku berjudul "Digital Literacy" yang terbit pada tahun 1997. Gislter, dalam wawancara yang dilakukan oleh Carolyn R. Poor selaku senior editor Educational Leadership, menyatakan bahwa literasi digital merupakan "the ability to understand information and - more important - to evaluate and integrate information in multiple formats that the computer can deliver" (Poor, 1997). Lebih lanjut, the American Library Association's (ALA) Digital Literacy Task Force (2013) mendefinisikan literasi digital sebagai "the ability to use information and communication technologies to find, evaluate, create, and communicate information, requiring both cognitive and technical skills." Selain itu, Jisc (2014) menjelaskan bahwa literasi digital merupakan "...those capabilities which fit an individual for living, learning and working in a digital society."

Terlihat pada definisi di atas, literasi digital dalam pandangan Gilster lebih mengarah pada kemampuan kognitif terhadap suatu informasi. ALA cenderung berfokus pada kemampuan teknis dalam pengoperasian teknologi informasi dan komunikasi (TIK). Sementara itu, tujuan literasi digital merupakan inti dari definisi yang diberikan oleh Jisc. Berdasarkan rangkuman ketiga definisi tersebut, dapat dipahami bahwa literasi digital merupakan kemampuan individu untuk mencari, memahami, mengevaluasi, membuat, mengintegrasikan, dan mengomunikasikan informasi pada berbagai perangkat TIK untuk dapat hidup, belajar, dan bekerja dalam sebuah masyarakat digital.

Sejauh ini, terlihat belum ada gerakan literasi digital yang secara spesifik mengarah kepada masyarakat akademik di perguruan tinggi, khususnya mahasiswa generasi milenial supaya dapat sukses belajar pada era pembelajaran digital. Mahasiswa generasi milenial yang dimaksud dalam penelitian ini adalah mahasiswa yang sedang menempuh pendidikan sarjana pada tahun pertama. Gerakan literasi digital yang sudah ada di Indonesia lebih ditargetkan kepada masyarakat umum (citizen) untuk dapat menjadi netizen dan digital citizen yang baik dengan memproduksi konten positif di dunia maya. Seperti 18 buku seri literasi digital yang diterbitkan atas kerja sama para pemangku kepentingan majemuk (multistakeholder), meliputi Kominfo, Center for Digital Society (CfDS) Universitas Gadjah Mada (UGM), ICT Watch!, Pusat Kajian Komunikasi (Puskakom) Universitas Indonesia (UI), dan ECPAT Indonesia yang diluncurkan bersama pada 31 Januari 2018 (Kominfo, 2018) mengusung tema literasi digital pada topik literasi informasi, media, dan TIK supaya masyarakat dapat menggunakan internet dengan baik.

Gerakan Literasi Nasional (GLN) telah diinisiasi oleh Kementerian Pendidikan dan Kebudayaan (Kemendikbud) pada tahun 2016. GLN merupakan gerakan literasi di lingkungan persekolah, keluarga, dan masyarakat dengan salah satu literasi yang digalakkan adalah literasi digital (Tim GLN, 2017: 8). GLN yang digalakkan oleh Kemendikbud lebih mengarah pada penggunaan media digital, perangkat komunikasi, dan internet dengan baik dan bijak dalam rangkan membina komunikasi dan interaksi dalam kehidupan sehari-hari melalui program yang dilakukan di sekolah. Kementerian Komunikasi dan Informatika (Kominfo) bekerja sama dengan berbagai kalangan nonpemerintah pada tahun 2017 juga menginisiasi Gerakan Nasional Literasi Digital \#SiBerkreasi (Kominfo, 2017). Gerakan ini berfokus pada penanggulangan konten negatif 
di Internet, seperti berita bohong (hoax), ujaran kebencian (hate speech), cyberbullying, pornografi, penipuan, dan radikalisme.

Pada sisi lain, saat ini telah menjadi tren dalam dunia akademik di perguruan tinggi untuk mengembangkan sebuah kursus terbuka yang dapat diikuti oleh siapa saja secara masif dalam jaringan. Perguruan tinggi mulai membuka diri seluas-luasnya bagi masyarakat umum untuk dapat memiliki pengalaman belajar dan mengikuti pembelajaran di perguruan tinggi melalui sistem yang disebuat sebagai massive open online courses atau MOOCs. MOOCs merupakan platform pembelajaran masif, online, dan terbuka yang termasuk dalam salah satu bentuk pembelajaran jarak jauh atau distance learning dengan skala lebih luas dan masif (Pomerol, Epelboin, \& Thouty, 2015: 1). Kebutuhan akan literasi digital dalam dunia akademik dan potensi MOOCs yang dapat diakses oleh siapa saja secara terbuka dan masif mendorong munculnya ide untuk mengembangkan digital literacy massive open online course atau yang disingkat DL-MOOCs untuk meningkatkan literasi digital mahasiswa generasi milenial supaya dapat sukses belajar di perguruan tinggi dalam era pembelajaran digital. DL-MOOCs ditujukan khusus kepada mahasiswa generasi milenial yang sedang menempuh perkuliahan tahun pertama supaya mereka memiliki literasi digital sejak awal mejalani proses perkuliahan di perguruan tinggi.

Generasi milenial atau millennial generation itu sendiri, adalah suatu generasi kelahiran awal tahun 1980-an sampai akhir tahun 2000-an. Pertama kali, kata millennial dicetuskan oleh Neil Howe dan William Strauss melalui sebuah buku dengan judul "Generations: The History of Amarica's Future" yang terbit pada tahun 1991. Istilah lain bagi generasi milenial adalah generasi Y dan istilah tersebut dicetuskan oleh Advertising Age pada tahun 1993 sebagai gambaran remaja yang berusia 11 tahun atau lebih muda dan remaja yang akan lahir pada 10 tahun berikutnya. Pada beberapa referensi, generasi ini juga disebut sebagai generasi me dan generasi we. Terdapat tiga generasi sebelum generasi milenial, yaitu mulai dari yang tertua silent atau traditionalist (19281945), baby boomers (1946-1964), dan generasi X (1965-1980). Berdasarkan pada kurun waktu tersebut, generasi milenial di Indonesia saat ini bisa terdiri dari pelajar atau mahasiswa, sedangkan dalam penelitian ini difokuskan pada mahasiswa yang sedang menempuh pendidikan sarjana pada tahun pertama.

Beberapa peneliti telah mulai meneliti dan mengkaji tentang literasi digital untuk keperluan akademik (digital literacy for academic purposes). Pada tahun 2016, Ukwoma, Iwundu, dan Iwundu mengkaji keterampilan literasi digital yang dimiliki dan digunakan mahasiswa University of Nigeria Nsukka (UNN) untuk menyelesaikan pekerjaan akademik. Hasil penelitian menunjukkan bahwa kemampuan literasi digital yang baik dapat meningkatkan kinerja akademik. Empat tahun sebelumnya, Shariman, Razak, dan Noor (2012) telah terlebih dulu mengkaji tentang kompetensi literasi digital untuk kebutuhan akademik (digital literacy competence for academic needs) pada mahasiswa dari tiga perguruan tinggi di Malaysia. Berdasarkan penelitian tersebut didapati bahwa mahasiswa sudah memiliki kompetensi literasi digital yang baik untuk keperluan sehari-hari, tetapi kompetensi literasi digital untuk keperluan akademik masih terbatas, seperti mahasiswa masih kesulitan mengevaluasi kebenaran informasi yang didapat untuk dijadikan rujukan belajar. Beberapa penelitian yang sudah ada dengan demikian memperlihatkan bahwa literasi digital untuk keperluan akademik penting dan perlu untuk terus dikaji secara lebih komprehensif dan mendalam.

Artikel ini mendiskusikan secara kritis kebutuhan pengembangan DL-MOOCs di perguruan tinggi yang secara spesifik mengkaji terkait: 1) kebutuhan literasi digital untuk keperluan akademik; 2) perkembangan MOOCs di dunia dan Indonesia; dan 3) kecakapan belajar abad 21 mahasiswa generasi milenial. Kajian ini menjadi landasan dalam pengembangan DL-MOOCs supaya pengembangannya terarah dan sesuai dengan kebutuhan nyata target pengguna. Pengembangan MOOCs dalam bidang literasi digital untuk keperluan akademik diharapkan dapat 
meningkatkan literasi digital generasi milenial supaya dapat sukses belajar pada era pembelajaran digital (digital learning) di perguruan tinggi dan melengkapi beberapa MOOCs yang sudah ada di dunia maupun Indonesia. MOOCs merupakan platform yang tepat untuk meningkatkan literasi digital karena selama proses pembelajaran dengan MOOCs secara otomatis membantu meningkatkan keterampilan literasi digital (Stewart, 2013). Hasil studi Littlejohn, Beetham, dan McGill (2012) juga menunjukkan bahwa berpartisipasi dalam pembelajaran secara online secara tidak langsung sudah mengembangkan keterampilan literasi digital. Apabila MOOCs diintegrasikan dengan program akademik dan kurikulum, hal tersebut dapat meningkatkan kinerja akademik (Lambert \& Alony, 2015).

\section{METODE PENELITIAN}

Studi merupakan penelitian pendahuluan dari rangkaian penelitian dan pengembangan digital literacy massive open online courses (DL-MOOCs) yang ditujukan untuk mengembangkan literasi digital mahasiswa generasi milenial supaya dapat sukses belajar di perguruan tinggi dalam era pembelajaran digital. Penelitian pendahuluan menggunakan metode kajian pustaka sederhana (simple literature review) dan survei yang dilakukan pada mahasiswa tahun pertama yang sedang menempuh perkuliahan pada program studi Strata 1 (S1) Pendidikan Pancasila dan Kewarganegaraan (PPKn), Fakultas Keguruan dan Ilmu Pendidikan (FKIP), Universitas Pamulang. Berikut ini gambaran proses kajian pustaka dan survei yang telah dilakukan.

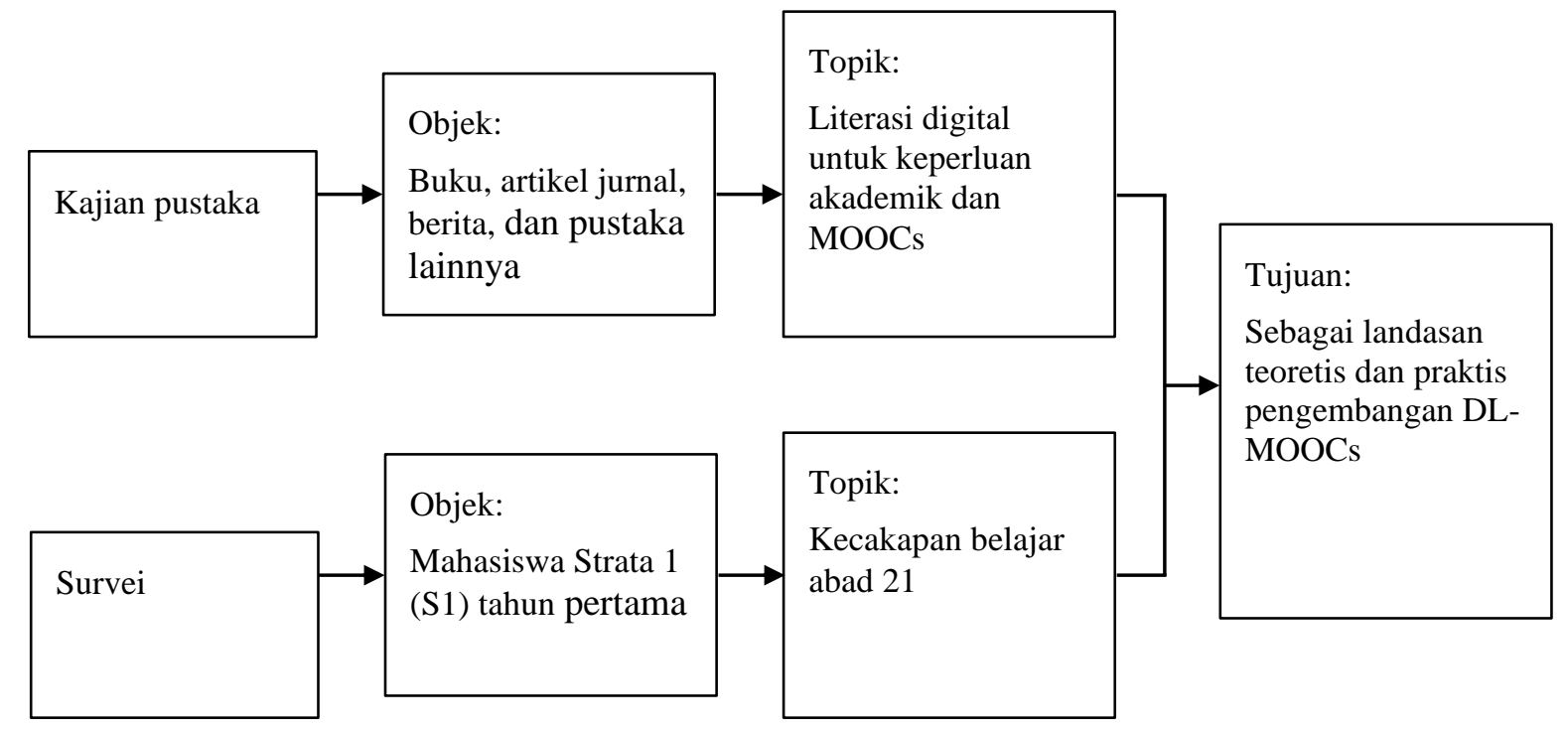

Gambar 1. Proses Kajian Pustaka dan Survei

Kajian pustaka terhadap berbagai buku, artikel jurnal, berita, dan sumber lain yang berkaitan dengan literasi digital dimaksudkan untuk memperkuat landasan teoretis terhadap pengembangan MOOCs pada bidang literasi digital untuk keperluan akademik (digital literacy for academic purposes). Penelitian survei digunakan untuk memperkuat landasan praktis terkait kebutuhan utama mahasiswa generasi milenial dalam hal literasi digital yang paling dibutuhkan untuk belajar berbasis digital di perguruan tinggi.

Survei dilakukan secara acak pada mahasiswa tahun pertama pada bulan Juli 2019. Terdapat sejumlah 245 mahasiswa mengisi survei secara sukarela. Instrumen survei dikembangkan dari National Educational Technology Standards for Students (NETS-S) yang dirumuskan oleh International Society for Technology in Education (ISTE) meliputi 7 komponen, yaitu: 


\section{1) empowered learner;}

2) digital citizen;

3) knowledge constructor;

4) innovative designer;

5) computational thinker;

6) creative communicator; dan

7) global collaborator.

Survei menggunakan 7 skala Likert dengan angka 1 merupakan nilai terendah dan angka 7 merupakan nilai tertinggi. Semua data yang terkumpul dianalisis dengan statistika deskriptif.

\section{HASIL DAN PEMBAHASAN}

Kajian pustaka yang telah dilakukan menemukan adanya kebutuhan terhadap literasi digital dalam dunia akademik. Analisis terhadap MOOCs di dunia maupun di Indonesia mendapati bahwa penyelenggara MOOCs bervariasi mulai dari perguruan tinggi, kementerian, dan organisasi lain dengan satu konten spesifik maupun campuran. Survei yang telah dilakukan mengungkap tingkat kecakapan belajar mahasiswa generasi milenial abad 21. Berikut ini merupakan hasil penelitian dan detail pembahasan secara lebih terperinci dan mendalam.

\subsection{Kebutuhan Literasi Digital untuk Keperluan Akademik}

Literasi digital dibutuhkan dalam menghadapi perkembangan ilmu pengetahuan dan teknologi informasi dan komunikasi (TIK) pada abad 21. TIK dengan perkembangannya yang pesat telah mentransformasi berbagai kegiatan warga (citizen) menjadi lebih modern berbasis digital. Tidak terlepas dalam proses belajar dan pembelajaran yang pelaksanaannya tidak lagi tradisional melainkan sudah berbasis digital (digital learning). Merujuk pada Ribble dan Bailey (2007: 10), literasi digital menjadi bagian dari sembilan elemen kewargaan digital (digital citizenship) sehingga dapat diasumsikan bahwa dengan membekali literasi digital yang memadai bagi generasi milenial dapat mendorong terwujudnya warga digital (digital citizen) yang baik dalam berkehidupan di dunia digital maupun di dunia nyata.

Literasi digital mencakup beberapa kemampuan yang dirumuskan oleh Jisc (2014) menjadi 7 elemen, yaitu 1) media literacy, 2) communication and collaboration, 3) career and identity management, 4) ICT literacy, 5) learning skills, 6) digital scholarship, dan 7) information literacy. Berikut ini gambaran tujuh elemen literasi digital.

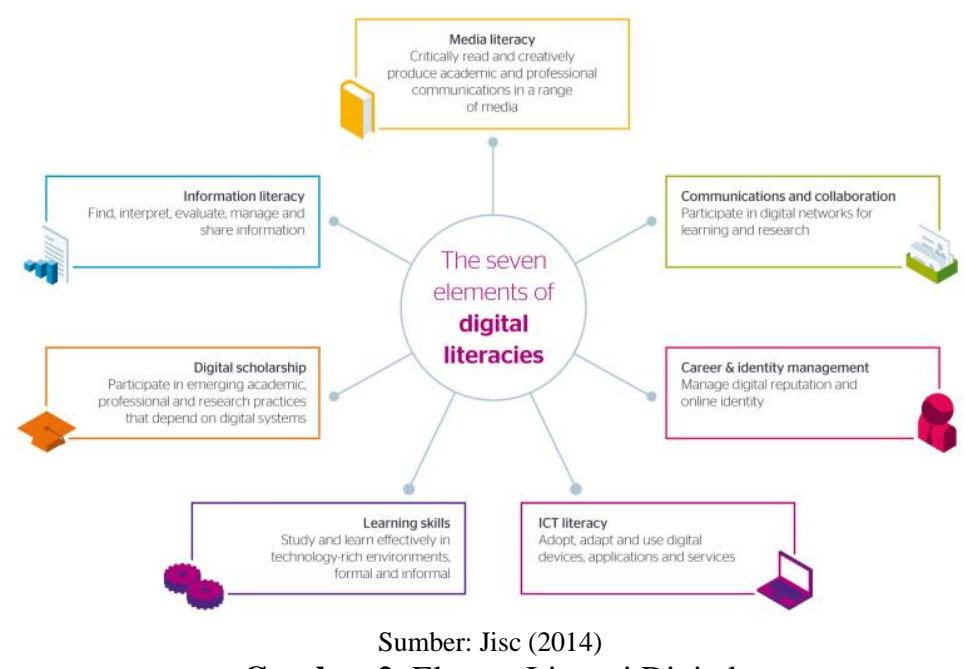

Gambar 2. Elemen Literasi Digital 
Pentingnya literasi digital telah mendorong para pemangku kepentingan (stakeholders), baik dari organisasi pemerintah maupun nonpemerintah, untuk bekerja sama memelopori gerakan literasi digital. Selain dua gerakan literasi digital oleh Kemendikbud dan Kominfo seperti yang sudah diulas pada bagian pendahuluan artikel ini, Kementerian Riset, Teknologi, dan Pendidikan Tinggi (Kemenristekdikti) yang pada Oktober 2019 sudah berubah nomenklatur, sejak tahun 2017 juga sedang gencar mengampanyekan pentingnya literasi digital bagi generasi milenial. Menteri Riset, Teknologi, dan Pendidikan Tinggi pada saat itu, Prof. Mohamad Nasir, membuat kebijakan yang mendukung penerapan pembelajaran hybrid/blended dan memfasilitasi pengembangan keterampilan baru untuk hybrid jobs (Belmawa, 2017) yang mana keterampilan baru ini mengarah pada keterampilan yang berkaitan dengan literasi digital. Direktur Jenderal Pembelajaran dan Kemahasiswaan, Intan Ahmad, juga menyampaikan bahwa pada era revolusi industri 4.0 diperlukan literasi baru berupa literasi data, teknologi, dan sumber daya manusia (Belmawa, 2018). Bahkan, pada Juli 2017, Direktur Pembelajaran Paristiyanti Nurwardani dengan Temasek Foundation sudah sempat menggagas kegiatan bernama Digital Literacy Framework (DLF) untuk meningkatkan produktivitas dan bisnis ekonomi digital (Belmawa, 2017).

Memang berbagai gerakan literasi digital telah dilakukan oleh para pemangku kepentingan (stakeholders) di Indonesia, tetapi belum ada suatu gerakan dengan fokus pada literasi digital untuk keperluan akademik (digital literacy for academic purposes). Beberapa gerakan literasi digital yang sudah ada, berlandaskan pada tujuh elemen literasi digital yang dirumuskan oleh Jisc (2014), cenderung lebih banyak mengarah pada literasi media (media literacy), literasi teknologi informasi dan komunikasi (ICT literacy), dan literasi informasi (information literacy). Sejauh ini belum terlihat gerakan yang mengarah pada keterampilan belajar (learning skills), keilmuan digital (digital scholarship), manajemen karir dan identitas (career \& identity management), dan komunikasi dan kolabirasi (communication and collaboration). Padahal selain literasi digital untuk keperluan sehari-hari, mahasiswa juga sangat membutuhkan literasi digital yang berkaitan dengan keterampilan belajar, keilmuan digital, pengelolaan karier dan identitas, serta komunikasi dan kolaborasi secara digital untuk keperluan akademik.

Literasi digital menjadi pondasi untuk dapat sukses dalam bidang akademik pada era digital. Littlejohn, Beetham, dan McGill (2012) mendefinisikan literasi digital dalam konteks akademik sebagai berbagai kemampuan yang dibutuhkan untuk berkembang dan mengembangkan diri dalam dunia pendidikan ketika mayoritas informasi dan komunikasi berbentuk digital. Lebih lanjut, terdapat tiga prinsip penting dalam literasi digital, yaitu 1) keterampilan dan pengetahuan untuk mengakses dan menggunakan berbagai macam perangkat dan aplikasi teknologi; 2) kemahiran dalam memahami dan menganalisis secara kritis konten dan aplikasi digital; dan 3) kemampuan untuk berkreasi menggunakan teknologi digital (Media Awareness Network, 2010). Literasi digital yang dikhususkan untuk keperluan akademik sudah menjadi kebutuhan di saat semua informasi yang dijadikan sebagai sumber belajar sudah menjadi digital dan pelaksanaan pembelajaran juga sudah mengarah pada pembelajaran digital. Kebutuhan sumber belajar di perguruan tinggi saat ini lebih mengarah pada sumber belajar yang dapat mendukung pembelajaran berbasis teknologi informasi dan komunikasi (Rahmadi et al., 2018).

\subsection{Perkembangan MOOCs di Dunia dan Indonesia}

Gerakan sumber belajar terbuka (Open Educational Resources - OER) yang salah satunya diinisiasi oleh Massachusetts Instutute of Technology (MIT) OpenCourseWare (OCW) dengan membuka konten kursus melalui internet kepada para pemelajar, pembelajar di institusi pendidikan, dan pebelajar independen pada tahun 2002 (Haber, 2014: 34) merupakan titik awal hadirnya MOOCs. Teruntuk pertama kalinya, MOOCs ditawarkan oleh Stephen Downes dan George 
Siemens dengan kursus bernama "Connectivism and Connective Knowledge 2008 (CCK08)" di University of Manitoba pada tahun 2008 (Downes, 2017: 16).

Menurut Haber (2014: 40), evolusi MOOCs menghadirkan dua model, yaitu cMOOCs (2008) dan XMOOC (2011) yang memiliki karakteristik yang sangat berbeda. Berdasarkan penjelasan dari Rhoads (2015: 63), konektivitas merupakan penekanan dari cMOOCs, sedangkan xMOOCs lebih menekankan pada ekstensi kursus yang diselenggarakan perguruan tinggi. Kenyataannya, perguruan tinggi saat ini banyak menggunakan MOOCs untuk untuk membuka sebagian dari mata kuliah yang dimiliki kepada masyarakat atau khalayak umum. Berikut ini timeline evolusi MOOCs terbaru yang digambarkan oleh Yuan dan Powell (2015).

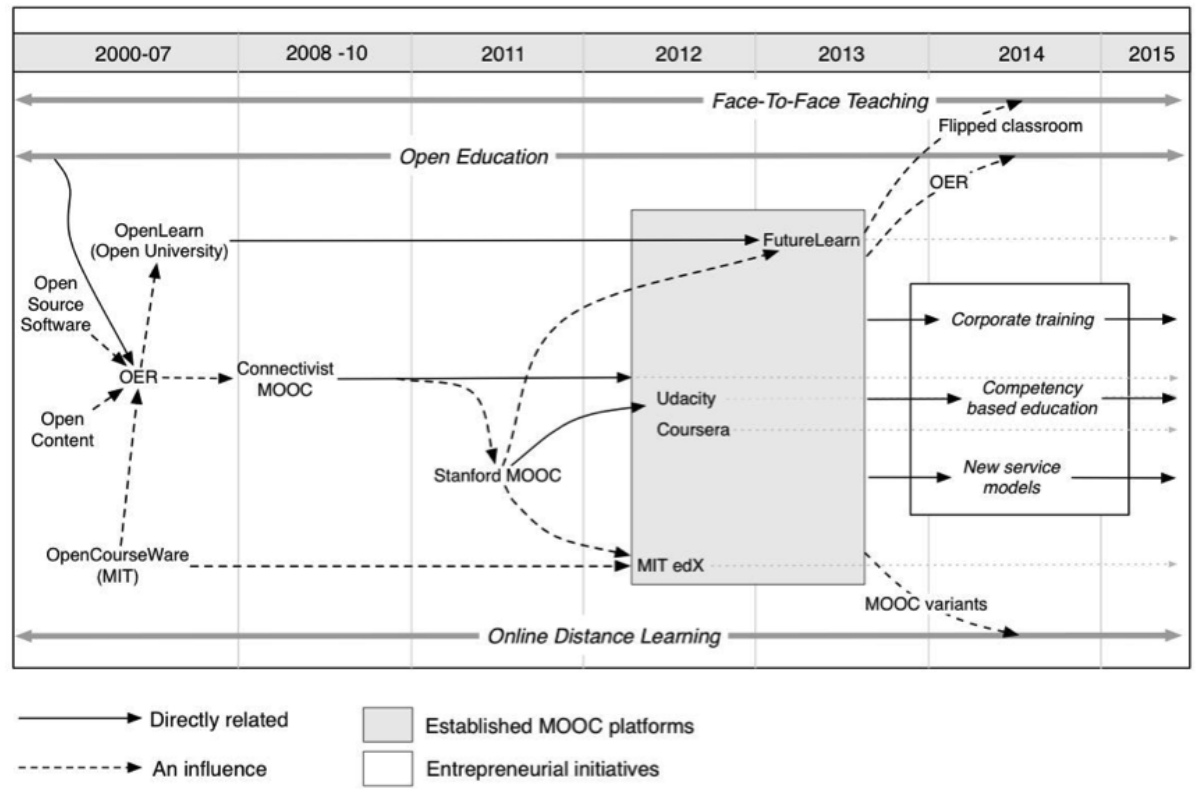

Sumber: Yuan dan Powell (2015)

Gambar 3. Timeline Evolusi MOOCs

Penyelenggaraan institusi pendidikan telah terdisrupsi dengan berkembangnnya MOOCs. Melalui kemampuan dalam memberikan fleksibilitas, kemudahan akses, dan kecepatan penyelesaian dengan biaya yang murah bagi siapa saja yang tertarik untuk belajar (Yuan \& Powell, 2013: 13). MOOCs secara nyata mendisrupsi model pendidikan di perguruan tinggi. Institusi pendidikan mulai berpikir ulang tentang mata kuliah yang akan ditawarkan dengan cara belajar yang berbeda dan pengalaman belajar yang unik dengan hadirnya MOOCs (Conole, 2016: 14). Sesungguhnya MOOCs telah memberikan keuntungan dan meningkatkan nilai tambah dalam dunia pendidikan (Waks, 2016: 1).

Selain itu, pengembangan Massive Open Online Courses (MOOCs) telah menjadi tren bagi institusi pendidikan pemerintah maupun nonpemerintah untuk membuka akses pendidikan dan menyebarluaskan ilmu pengetahuan bagi seluruh umat manusia (education for all) supaya dapat belajar sepanjang hayat (lifelong learning). Beberapa MOOCs yang sudah ada saat ini, berisi pembelajaran yang mengajarkan tentang konten (learning what to learn), belum ada MOOCs yang berfokus pada pembelajaran tentang bagaimana cara belajar (learning how to learn). Padahal, belajar bagaimana cara belajar merupakan bekal utama untuk dapat belajar sepanjang hayat.

Berdasarkan data dari Class Central, sebuah mesin pencari dan situs review MOOCs yang telah melakukan survei pada tahun 2017, sudah terdapat 33 MOOCs dari berbagai belahan dunia. Setiap MOOCs memiliki konten dan model bisnis yang berbeda. MOOCs yang terdaftar dibawah ini memiliki konten yang beragam pada berbagai topik sebagaimana topik-topik yang diajarkan di 
universitas. MOOCs dapat diikuti secara gratis sepenuhnya atau hanya sebagian. Kebanyakan MOOCs menggandeng universitas untuk mengisi kontennya.

Tabel 1. Daftar MOOCs di Dunia (sumber: Class Central, 2017)

\begin{tabular}{|c|c|c|c|}
\hline No. & Nama MOOCs & URL & Negara \\
\hline 1. & Coursera & www.coursera.org & Amerika \\
\hline 2. & $\mathrm{EdX}$ & www.edx.org & Amerika \\
\hline 3. & FutureLearn & www.futurelearn.com & Inggris \\
\hline 4. & XuetangX & www.xuetangx.com & Cina \\
\hline 5. & Udacity & www.udacity.com & Amerika \\
\hline 6. & Kadenze & www.kadenze.com & Amerika \\
\hline 7. & Canvas Network & www.canvas.net & Amerika \\
\hline 8. & Stanford Languita & www.lagunita.stanford.edu & Amerika \\
\hline 9. & Miriada X & www.miriadax.net & Spanyol \\
\hline 10. & MexicoX & www.mexicox.gob.mx & Meksiko \\
\hline 11. & France Universite Numerique & www.fun-mooc.fr & Perancis \\
\hline 12. & EduOpen & www.eduopen.org & Itali \\
\hline 13. & ThaiMOOC & www.thaimooc.org & Tailand \\
\hline 14. & Federica.eu & www.federica.eu & Italy \\
\hline 15. & Swayam & www.swayam.gov.in & India \\
\hline 16. & NPTEL & www.onlinecourses.nptel.ac.in & India \\
\hline 17. & CNMOOC & www.cnmooc.org & Cina \\
\hline 18. & Chinese MOOCs & www.chinesemooc.org & Cina \\
\hline 19. & University of China MOOC & www.icourse163.org & Cina \\
\hline 20. & ewant & www.ewant.org & Taiwan \\
\hline 21. & Edraak & www.edraak.org & Jordania \\
\hline 22. & EMMA & www.platform.europeanmoocs.eu & Eropa \\
\hline 23. & Zhihuishu & www.zhihuishu.com & Cina \\
\hline 24. & Open HPI & www.open.hpi.de & Jerman \\
\hline 25. & Gacco & www.gacco.org & Jepang \\
\hline 26. & Fisdom & www.fisdom.org & Jepang \\
\hline 27. & OpenLearning & www.open.netlearning.co.jp & Jepang \\
\hline 28. & JMOOC & www.jmooc.jp & Jepang \\
\hline 29. & Open Education & www.openedu.ru & Rusia \\
\hline 30. & Open Education & www.openedu.tw & Taiwan \\
\hline 31. & K-MOOC & www.kmooc.kr & Korea \\
\hline 32. & IndonesiaX & www.indonesiax.co.id & Indonesia \\
\hline 33. & Prometheus & www.edx.prometheus.org & Ukraina \\
\hline
\end{tabular}


Seperti terlihat pada tabel 1, hanya IndonesiaX yang termasuk dalam daftar. Masih ada setidaknya 7 MOOCs di Indonesia selain IndonesiaX. Berbeda dengan tren di luar negeri, MOOCS di Indonesia mengusung topik materi atau konten yang spesifik meskipun juga terdapat MOOCs dengan materi campuran. Selain itu, belum ada MOOCs di Indonesia yang berisi tentang literasi digital, terutama literasi digital untuk keperluan akademik (digital literacy for academic purposes).

Tabel 2. Daftar MOOCs di Indonesia (sumber: observasi peneliti secara online)

\begin{tabular}{|c|c|c|c|c|c|}
\hline No. & MOOC & URL & Institus Penyelenggara & $\begin{array}{l}\text { Jlh. } \\
\text { Materi }\end{array}$ & Topik Materi \\
\hline 1. & CodeSaya & www.codesaya.com & Coder Indonesia & 3 & Coding \\
\hline 2. & FOCUS & www.focus.fisipol.ugm.ac.id & Fisipol UGM & 12 & $\begin{array}{l}\text { Sosial dan } \\
\text { Politik }\end{array}$ \\
\hline 3. & IndonesiaX & www.indonesiax.co.id & IndonesiaX & 25 & $\begin{array}{l}\text { Ekonomi dan } \\
\text { Manajemen }\end{array}$ \\
\hline 4. & MOOCs-UT & www.moocs.ut.ac.id & Universitas Terbuka & 7 & Campuran \\
\hline 5. & $\begin{array}{l}\text { MOOC- } \\
\text { SEAMOLEC }\end{array}$ & www.mooc.seamolec.org & SEAMOLEC & 99 & $\begin{array}{l}\text { TIK dan } \\
\text { Pendidikan } \\
\text { Vokasi }\end{array}$ \\
\hline 6. & UCEO & www.ciputrauceo.com & Universitas Ciputra & 15 & $\begin{array}{l}\text { Bisnis dan } \\
\text { Manajemen }\end{array}$ \\
\hline 7. & SPADA & www.spada.ristekdikti.go.id & Kemenristekdikti & 32 & Campuran \\
\hline 8. & Sekolah Pintar & www.sekolahpintar.com & Sekolah Pintar & 67 & $\begin{array}{l}\text { Bisnis dan } \\
\text { Teknologi }\end{array}$ \\
\hline
\end{tabular}

Tabel 2 menunjukkan bahwa sejauh ini baru terdapat 8 MOOCs di Indonesia. Penyelenggara MOOCs di Indonesia bervariasi mulai dari perguruan tinggi, kementerian, dan organisasi lain yang bergerak pada bidang sesuai dengan MOOCs yang dikembangkan. Kebanyakan MOOCs masih memiliki jumlah kursus yang terbatas di bawah 50 kursus dengan topik kursus yang bervariasi.

Sebuah peta gerakan literasi digital di Indonesia telah dibuat oleh Kurnia dan Astuti (2017) dengan melibatkan Jaringan Peneliti Literasi Digital (Japelidi) mengkaji pelaku, ragam kegiatan, kelompok sasaran, dan mitra dalam gerakan literasi digital. Perguruan tinggi merupakan pelaku dominan $(56,14 \%)$ yang disusul oleh pemerintah $(14,34 \%)$, komunitas $(13,52 \%)$, lembaga swadaya masyarakat $(5,32 \%)$, sekolah $(3,68 \%)$, korporasi $(3,68 \%)$, asosiasi dan ormas $(2,86 \%)$, dan media $(0,4 \%)$ dalam gerakan literasi digital di Indonesia. Sayangnya, kegiatan yang dilakukan lebih banyak menggunakan cara konvensional seperti sosialisasi dan ceramah satu arah. Pengembangan MOOCs literasi digital untuk keperluan belajar dan pembelajaran di perguruan tinggi dapat menjadi medium baru dalam menggalakkan literasi digital sekaligus dapat memperkuat dan meningkatkan peran perguruan tinggi sebagai promotor gerakan literasi digital di Indonesia.

\subsection{Kecakapan Belajar Abad 21 Mahasiswa Generasi Milenial}

Generasi milenial tumbuh berkembang pada sebuah era dengan perubahan yang sangat cepat, yaitu pada era Milenium (KPMG, 2017). Perubahan yang terjadi terutama dalam bidang teknologi informasi dan komunikasi (People Scout, 2016: 3). Generasi yang diyakini akan membawa banyak 
perubahan ini, merupakan generasi pertama yang tumbuh menjadi dewasa pada era Milenium baru (Frey, 2018: 6). Penuh percaya diri, ekspresif, liberal, ceria, dan terbuka dengan perubahan (Pew Research Center, 2010:1); pintar, terdidik, berpikiran terbuka, dan independen (Greenberg \& Weber, 2008: 13); mudah bergaul, optomis, bertalenta, berpendidikan baik, kolaboratif, berpikiran terbuka, berpengaruh, dan berorientasi pada pencapaian (Raines, 2003: 11); berjumlah lebih banyak, lebih sejahtera, berpendidikan lebih baik, dan lebih beragam secara etis (Howe \& Strauss, 2000: 4) merupakan beberapa karakteristik dari generasi milenial. Terlihat dengan jelas bahwa bahwa generasi milenial memiliki karakter yang sangat berbeda dan unik dibanding dengan generasi-generasi pendahulunya.

Hasil survei yang dilakukan pada mahasiswa generasi milenial yang sedang menempuh perkuliahan tahun pertama terkait dengan kecakapan belajar abad 21 menunjukkan bahwa terdapat kompetensi yang sangat rendah pada komponen creative collaborator yang hanya mendapatkan rata-rata 4,86 dari nilai rata-rata paling tinggi yaitu 7 . Kompetensi terendah kedua terletak pada komponen innovative designer yang mendapatkan nilai rata-rata 4,96, sedangkan kompetensi tertinggi terletak pada komponen global collaborator dengan nilai rata-rata 5,60.

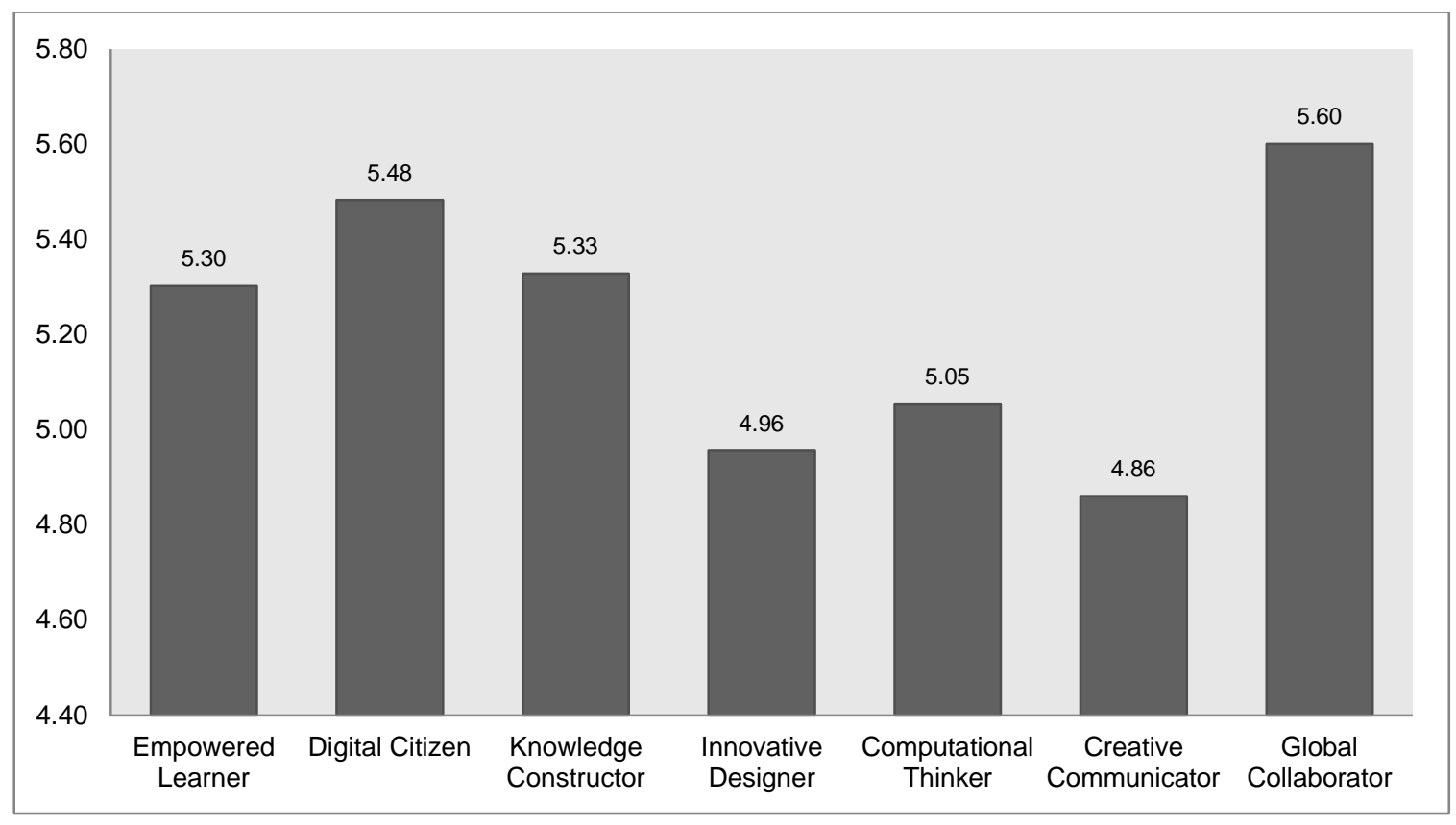

Gambar 4. Hasil Survei Kecakapan Belajar Abad 21

Komponen creative collaborator berkaitan dengan kemampuan dalam;1) memilih perangkat dan aplikasi teknologi yang tepat untuk menyampaikan pesan dan ide dalam berkomunikasi; 2) membuat karya orisinil, daur ulang, atau remix ke dalam kreasi baru dengan menggunakan berbagai sumber dari dunia digital secara bertanggung jawab; 3) mengomunikasikan ide-ide rumit dengan jelas dan efektif dengan membuat atau menggunakan berbagai objek digital, seperti visualisasi, model, atau simulasi; dan 4) mempublikasikan atau menyajikan konten dengan menyesuaikan isi pesan dan media sesuai dengan khalayak yang dituju. Selain itu, komponen innovative designer berkaitan dengan kemampuan dalam; 1) menggunakan kreativitas untuk menghasilkan ide, menguji teori, menciptakan karya inovatif, atau memecahkan masalah nyata; 2) menggunakan perangkat digital untuk merencanakan dan mengelola kreativitas dengan mempertimbangkan kendala dan risiko; 3) memilih dan menggunakan perangkat digital untuk merencanakan dan mengelola 
kreativitas dengan mempertimbangkan kendala dan risiko; dan 4) menunjukkan toleransi terhadap sesuatu yang belum jelas pada berbagai masalah dalam kehidupan nyata.

Secara lebih mendetail dan mendalam, berdasarkan data yang didapat, salah satu nilai rata-rata terendah dari keempat kompetensi dalam komponen creative collaborator terletak pada kemampuan dalam membuat karya orisinil, daur ulang, atau remix ke dalam kreasi baru dengan menggunakan berbagai sumber dari dunia digital secara bertanggung jawab. Data tersebut diperkuat dengan kenyataan bahwa banyak mahasiswa yang sering melakukan salin-tempel ketika menyusun makalah untuk keperluan presentasi dalam proses perkuliahan secara tidak bertanggung jawab.

Sebaliknya, sebagai yang tertinggi, komponen global collaborator berkaitan dengan kemampuan dalam; 1) menggunakan perangkat digital untuk terhubung dengan mahasiswa lain dari berbagai latar belakang dan budaya dengan penuh toleransi; 2) menggunakan teknologi untuk berkolaborasi dengan orang lain termasuk dengan teman sebaya, pakar, atau anggota komunitas untuk melihat isu dan masalah dari berbagai sudut pandang; 3) berkontribusi dalam kerja kelompok serta menjalankan peran dan tanggung jawab dengan baik untuk berkolaborasi secara efektif demi tujuan bersama; dan 4) memperhatikan isu-isu lokal maupun global dan menggunakan teknologi untuk berkolaborasi dengan orang lain dalam rangka mencari solusi. Apabila dicermati, keempat hal tersebut merupakan kemampuan yang erat dalam kehidupan sehari-hari, seperti terhubung dengan sesama mahasiswa merupakan kegiatan komunikasi harian yang dilakukan oleh setiap mahasiswa. Sangat wajar jika berdasarkan hasil survei mahasiswa komponen tersebut mendapatkan nilai tertinggi.

Berdasarkan hasil survei, kecakapan belajar mahasiswa harus ditingkatkan terutama pada komponen creative collaborator, khususnya terkait dengan kemampuan dalam membuat karya orisinil, daur ulang, atau remix ke dalam kreasi baru dengan menggunakan berbagai sumber dari dunia digital secara bertanggung jawab. Prioritas peningkatan kompetensi diikuti dengan komponen innovative designer dimana mahasiswa harus dapat menggunakan kreativitas untuk menghasilkan ide, menguji teori, menciptakan karya inovatif, atau memecahkan masalah nyata melalui berbagai perangkat digital. Hasil survei ini sangat bermanfaat untuk memberikan arahan khususnya terhadap prioritas kursus yang akan dikembangkan dalam DL-MOOCs dan umumnya terhadap peningkatan literasi digital untuk keperluan akademik di masa depan.

\section{PENUTUP}

Kebutuhan literasi digital untuk keperluan akademik sangat mendesak mengingat sejauh ini belum ada gerakan literasi digital yang secara spesifik mengarah untuk keperluan akademik. Perkembangan MOOCs membuka kesempatan luas untuk dapat digunakan sebagai platform pembelajaran terbuka dan masif untuk mengembangkan literasi digital mahasiswa generasi milenial karena dengan mengakses MOOCs itu sendiri dapat otomatis mengembangkan keterampilan literasi digital. Kecakapan belajar mahasiswa generasi milenial abad 21 masih sangat rendah pada komponen creative collaborator dan innovative designer.

Implikasi dari kajian pendahuluan ini, menunjukkan urgensi pengembangan MOOCs yang berfokus pada literasi digital untuk keperluan akademik. Pengembangan literasi digital melalui MOOCs merupakan suatu langkah yang tepat karena ketika mengikuti kursus dalam MOOCs membuat mahasiswa generasi milenial terbiasa belajar melalui platform digital. Lebih jauh, mengingat bahwa mahasiswa generasi milenial secara spesifik memeliki kemampuan yang paling rendah dalam membuat karya orisinil, daur ulang, atau remix ke dalam kreasi baru dengan menggunakan berbagai sumber dari dunia digital secara bertanggung jawab. Dengan demikian, 
kursus yang harus dikembangkan pertama kali dalam MOOCs diarahkan untuk meningkatkan literasi digital mahasiswa generasi milenial dalam belajar belajar melalui aneka sumber belajar digital dengan membuat karya orisinil, daur ulang, atau remix ke dalam kreasi baru secara bertanggung jawab.

Studi pendahuluan ini terbatas mengukur kecakapan belajar mahasiswa generasi milenial abad 21 yang sedang menempuh perkuliahan tahun pertama pada satu prodi di satu perguruan tinggi swasta. Studi selanjutnya dapat memperluas jangkauan populasi dan sample yang terdiri oleh mahasiswa dari berbagai tingkat tahun, prodi, dan perguruan tinggi. Temuan studi selanjutnya dapat dijadikan landasan untuk mengembangkan salah satu kursus pada DL-MOOCs sesuai dengan kebutuhan target pengguna yang spesifik terkait dengan literasi digital untuk keperluan akademik.

\section{Ucapan Terimakasih}

Penulis perlu menyampaikan ucapan terima kasih kepada Direktorat Riset dan Pengabdian Masyarakat (DRPM), Direktorat Jenderal Penguatan Riset dan Pengembangan, Kementerian Riset, Teknologi, dan Pendidikan Tinggi (Kemenristekdikti) yang telah mendanai penelitian dan pengembangan digital literacy massive open online course (DL-MOOCs) melalui program hibah penelitian tahun 2019 dalam skema Penelitian Dosen Pemula (PDP).

\section{DAFTAR PUSTAKA}

Beetham, H. \& Sharpe, R. 2010. Digital literacy framework. JISC - The Design Studio. Diakses 13 Mei 2018, dari http://jiscdesignstudio.pbworks.com/w/page/46740204/Digital\%20literacy\%20framework

Belmawa. (2017). Bersama Mewujudkan Mutu dan Daya Saing Pendidikan Tinggi di Era Digital. Diakses 12 Mei 2018, dari http://belmawa.ristekdikti.go.id/2017/12/19/bersama-mewujudkan-mutu-dan-dayasaing-pendidikan-tinggi-di-era-digital/

Belmawa. (2017). Direktorat Pembelajaran Bahas Program Digital Literacy Framework. Diakses 12 Mei 2018, dari http://belmawa.ristekdikti.go.id/2017/07/29/direktorat-pembelajaran-bahas-program-digitalliteracy-framework/

Belmawa. (2018). Era Revolusi Industri 4.0: Perlu Persiapkan Literasi Data, Teknologi dan Sumber Daya Manusia. Diakses 12 Mei 2018, dari http://belmawa.ristekdikti.go.id/2018/01/17/era-revolusi-industri4-0-perlu-persiapkan-literasi-data-teknologi-dan-sumber-daya-manusia/

Conole, G. (2016). MOOCs as disruptive technologies: strategies for enhancing the learner experience and quality of MOOCs. Revista de Educación a Distancia (RED), (50). https://doi.org/10.6018/red/50/2

Downes, S. (2017). New Models of Open and Distributed Learning. Dalam M. Jemni, Kinshuk, \& M. K. Khribi (Ed.), Open Education: from OERs to MOOCs (hlm. 1-22). Berlin, Heidelberg: Springer Berlin Heidelberg. https://doi.org/10.1007/978-3-662-52925-6_1

Frey, W. H. (2018). The millennial generation: a demographic bridge to Amarica's diverse future.

Greenberg, E. H., \& Weber, K. (2008). Generation we: how millennial youth are taking over America and changing our world forever. Emeryville, CA: Pachatusan.

Haber, J. (2014). MOOCs. Cambridge, Massachusetts: MIT Press.

Howe, N., \& Strauss, W. (2000). Millennials rising: the next great generation lby Neil Howe and Bill Strauss ; cartoons by R.J. Matson. New York: Vintage Books.

Jisc. (2014). Developing digital literacies. Diakses 11 Mei 2018, dari https://www.jisc.ac.uk/guides/developing-digital-literacies

Kementerian Komunikasi dan Informatika. (t.t.). Diakses 12 Mei 2018, dari https://kominfo.go.id/index.php/content/detail/10801/siaran-pers-no-184hmkominfo102017-tentang- 
gerakan-nasional-literasi-digital-siberkreasi-ajak-masyarakat-sebar-konten-positif/0/siaran_pers

Kominfo. (2018). Siaran Pers No.21/HM/KOMINFO/01/2018 tentang Peluncuran Bersama 18 Buku Seri Literasi Digital "Kerja Bersama Pemangku Kepentingan Internet Indonesia Giatkan Literasi Digital Indonesia." Diakses 12 Mei 2018, dari https://kominfo.go.id:443/content/detail/12505/siaran-persno21hmkominfo012018-tentang-peluncuran-bersama-18-buku-seri-literasi-digital-kerja-bersamapemangku-kepentingan-internet-indonesia-giatkan-literasi-digital-indonesia/0/siaran_pers

KPMG. (2017). Meet the millennials. United Kingdom: KPMG International.

Kurnia, N., \& Astuti, S. I. (2017). Peta Gerakan Literasi Digital di Indonesia: Studi Tentang Pelaku, Ragam Kegiatan, Kelompok Sasaran dan Mitra yang Dilakukan oleh Japelidi. Informasi, 47(2), 149. https://doi.org/10.21831/informasi.v47i2.16079

Lambert, S. R. \& Alony, I. (2015). Embedding MOOCs in academic programs as a part of curriculum transformation: a pilot case study. International Conference on Open and Flexible Education (pp. 1-9). Hong Kong: Open University of Hong Kong.

Littlejohn, A., Beetham, H., \& McGill, L. (2012). Learning at the digital frontier: A review of digital literacies in theory and practice. Journal of Computer Assisted Learning, 28, 547-556. doi:10.1111/j.1365-2729.2011.00474.x

Media Awareness Network. (2010). Digital literacy in Canada: From inclusion to transformation. A MOOCs 2017: A Year in Review Class Central. Diakses 12 Mei 2018, dari https://www.classcentral.com/moocs-year-in-review-2017

People Scout. (2016). All about millennials: crossing a multi-generational talent pool.

Pew Research Center. (2010). Millennials: a portrait of generation next.

Pomerol, J.-C., Epelboin, Y., \& Thoury, C. (2015). MOOCs: design, use and business models. London, UK ; Hoboken, NJ: ISTE.

Poor, C. R. (1997). A New Digital Literacy: A Conversation with Paul Gilster. Integrating Technology into Teaching, 55(3).

Rahmadi, I. F., Khaerudin, K., \& Kustandi, C. (2018). Kebutuhan Sumber Belajar Mahasiswa yang Mendukung Pembelajaran Berbasis Teknologi Informasi dan Komunikasi di Perguruan Tinggi. JTP Jurnal Teknologi Pendidikan, 20(2), 120-136. https://doi.org/10.21009/JTP2002.3

Raines, C. (2003). Connecting Generations: The Sourcebook for a New Workplace. Menlo Park, CA: Crisp Publications.

Rhoads, R. A. (2015). MOOCs, high technology, \& higher learning. Baltimore: Johns Hopkins University Press.

Schwab, K. (2016). The fourth industrial revolution (First U.S. edition). New York: Crown Business.

Shariman, T. P. N. T., Razak, N. A., \& Noor, N. F. M. (2012). Digital Literacy Competence for Academic Needs: An Analysis of Malaysian Students in Three Universities. Procedia - Social and Behavioral Sciences, 69, 1489-1496. https://doi.org/10.1016/j.sbspro.2012.12.090

Stewart, B. (2013). Massiveness + Openness = New Literacies of Participation? MERLOT Journal of Online Learning and Teaching, 9(2), 228-238.

Strauss, W., \& Howe, N. (1991). Generations: the history of America's future, 1584 to 2069 (1st ed). New York: Morrow.

The American Library Association's (ALA) Digital Literacy Task Force. (2013). Digital literacy, Libraries, and Public Policy.

Tim GLN. (2017). Peta Jalan Gerakan Literasi Nasional. Jakarta: Kementerian Pendidikan dan Kebudayaan.

Ukwoma, S. C., Iwundu, N. E., \& Iwundu, I. E. (2016). Digital literacy skills possessed by students of UNN, implications for effective learning and performance: A study of the MTN Universities Connect Library. New Library World, 117(11/12), 702-720. https://doi.org/10.1108/NLW-08-2016-0061

Waks, L. J. (2016). The evolution and evaluation of massive open online courses: MOOCs in motion. New York, NY: Palgrave McMillan.

Yuan, L., \& Powell, S. (2013). MOOCs and Open Education: Implications for Higher Education. JISC CETIS. https://doi.org/10.13140/2.1.5072.8320 
JURNAL STUDI KOMUNIKASI DAN MEDIA

Vol. 24 No. 1 Juni 2020 Hal : 91 - 104

Yuan, L., \& Powell, S. J. (2015). Partnership model for entrepreneurial innovation in open online learning. Elearning Papers, 41. 